\title{
COMPARISON BETWEEN IRAQI AND EUROPEAN ETHER EXTRACT OF PROPOLIS ON STAPHYLOCOCCUS AUREUS ISOLATED FROM MINCED MEAT
}

\author{
T.A. ABDULLAH \\ Department of Veterinary Public Health, College of Veterinary Medicine, \\ University of Mosul, Mosul, Iraq.
}

Received: 24 July 2016; Accepted: 19 September 2016

\begin{abstract}
This study was conducted for isolation and identification of staphylococcus aureus from minced meat and evaluation of sensitivity of these strains to antibiotics. Also, this study aimed to assess the activity of Iraqi ethanol extract of propolis (EEP) against S.aureus compared to European ethanol extract of propolis at $10 \%$, $15 \%$. $20 \%$ and $30 \%$ to both types of propolis. Thirteen samples of minced meat revealed positive results for isolation of S.aureus with a ratio of (21\%). Iraqi EEP showed antibacterial activity against S.aureus at $3 \mu \mathrm{g}$ with average of inhibition zone 18.84 \pm 0.256 compared to European EEP which gave inhibition zone against the growth of S.aureus $12.84 \pm 0.354$ at same concentration. Other concentration of EEP gave low sensitivity against $S$. aureus strains which mean that Iraqi EEP have a high activity against these strains related to flavonoides and phenols activity presented in Iraqi EEP. All strains of S.aureus isolated from minced meat showed high sensitivity to Cephtriaxon at $10 \mu \mathrm{g}$ while all of them showed high resistance to Methacillin, Gentamycin and Penicillin at $10 \mu \mathrm{g}$ concentration.
\end{abstract}

Key words: Iraqi, European ether extract, Propolis, Staphylococcus aureus, Minced meat

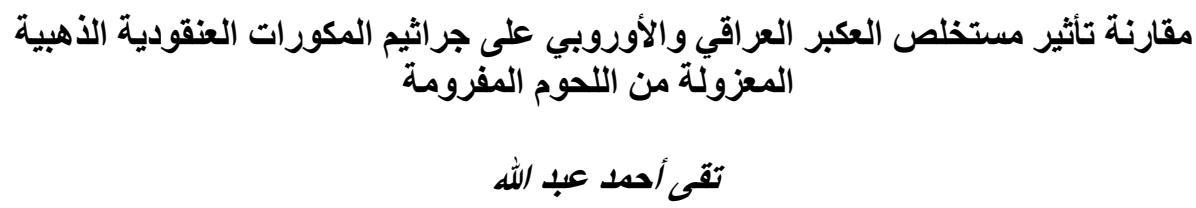

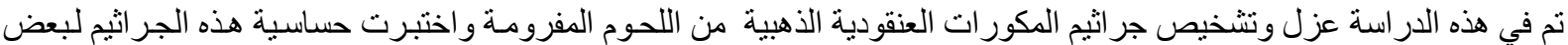

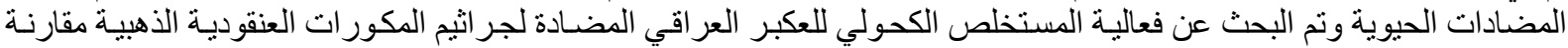

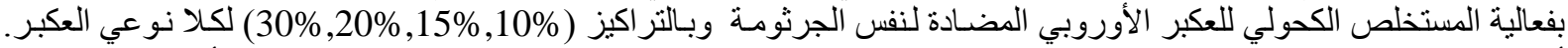

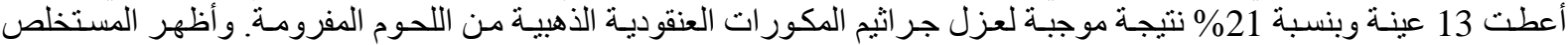

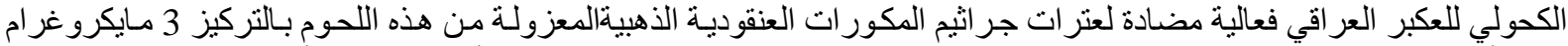

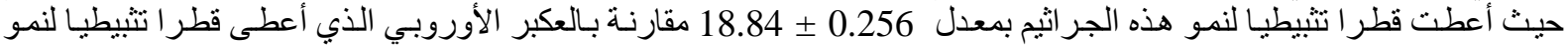

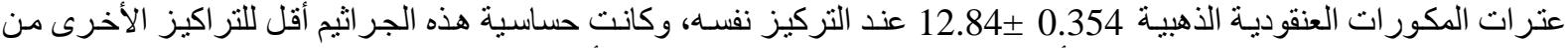

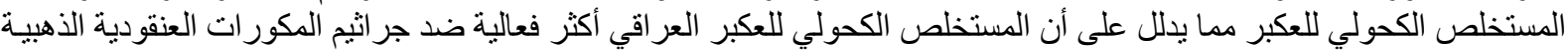

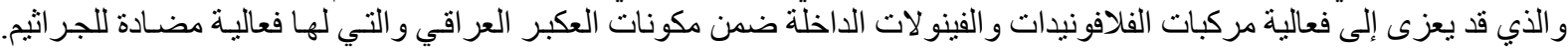

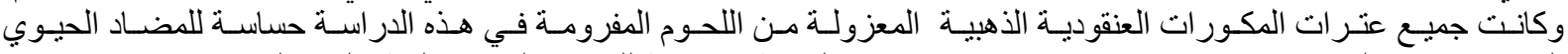

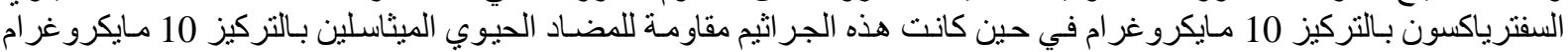

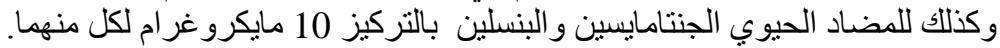

\section{INTRODUCTION}

مقدمـة

العكبر مادة راتنجية معقدة التركيب تجمع بو اسطة نحل العسل من مصادر نباتية مختلفة ومنذ القدم استخدم العكبر في علاج الكثير من

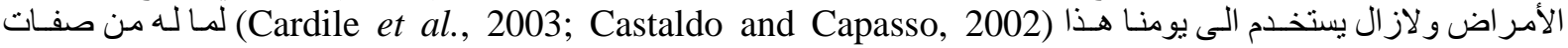

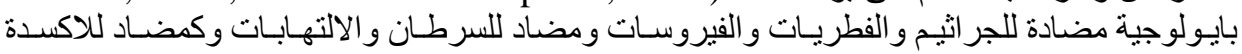

Corresponding author: Dr. T. A. ABDULLAH

E-mail address: montaha_hassan99@yahoo.com

Present address: Department of Veterinary Public Health, College of Veterinary Medicine, University of Mosul, Mosul, Iraq. 
ان تأثير العكبر المضـاد (Wang et al., 2004; Kartal et al., 2003; Prytzyk et al., 2003; Akao et al., 2003)

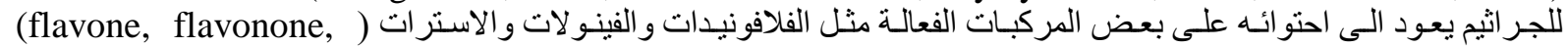

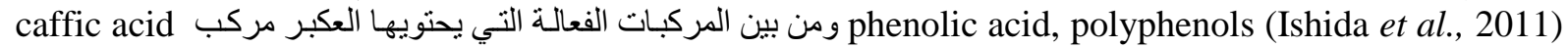

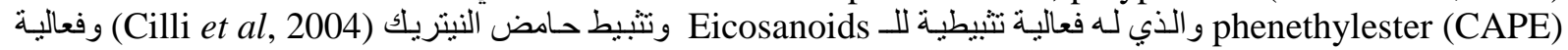
مضـادة للجر اثيم (Celik et al., 2007; Havsteen, 2002). وبينت دراسـة اجريت على العكبـر العر اقي ان العكبر العر اقي

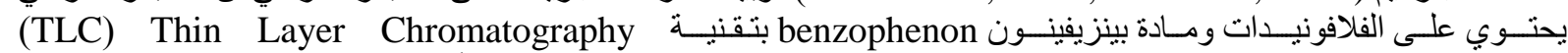
(Raghukumar et al.,2010; Kilic et al., 2005) تأثير العكبر على المكورات العنقوديـة (AL-Nema, 2011)

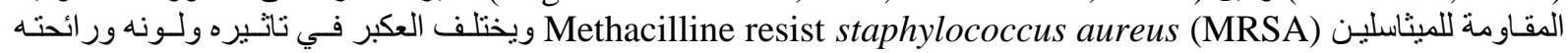

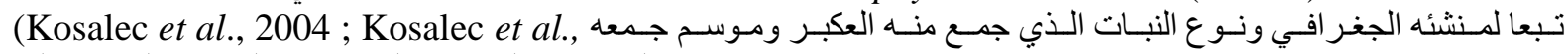
توثن 2003 ; Bankova et al., 2002; Sforcin et al., 2000)

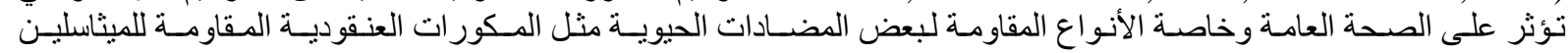

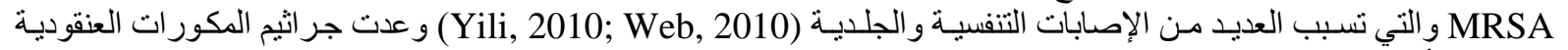

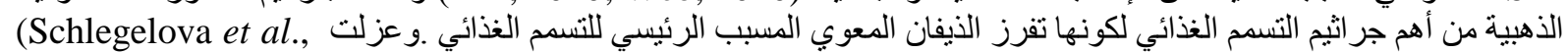

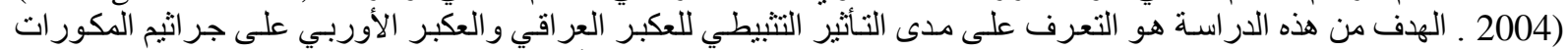

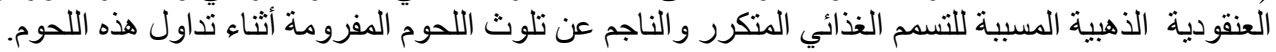

\section{MATERIALS AND METHODS المواد وطر ائق البحث}

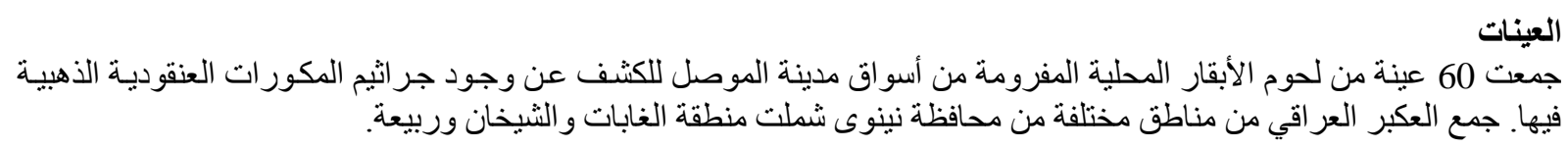
طريقة تحضير المستخلص الكحولي للعكبر:

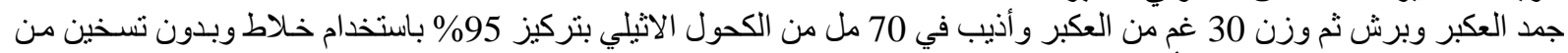

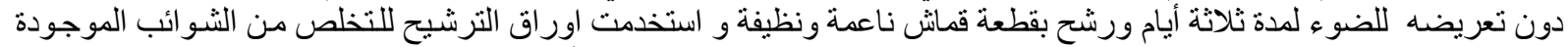

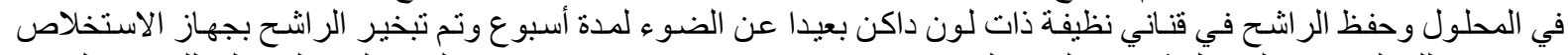

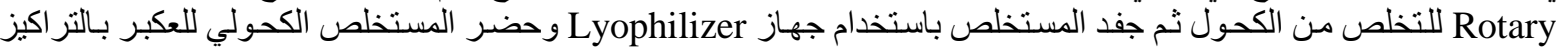

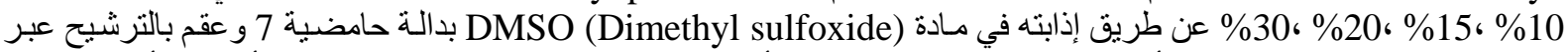

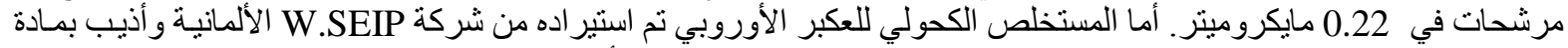

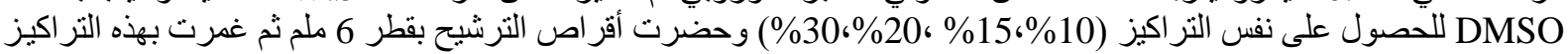
.(Lu et al., 2005 ; NCCLS, 2004 ; Krell, 1996)

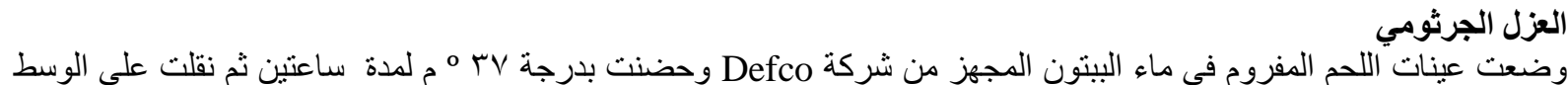

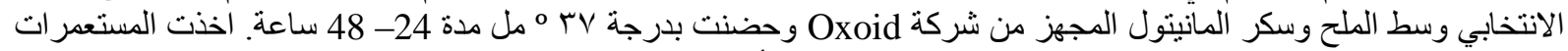

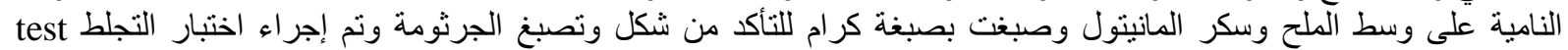
Coagulase

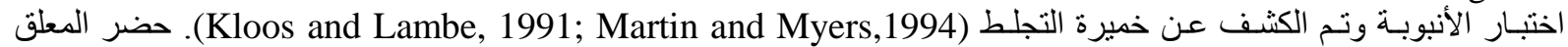

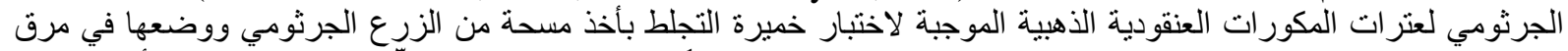

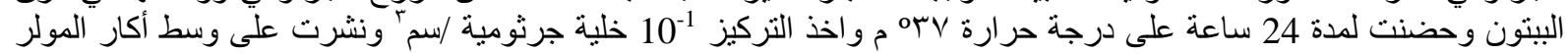

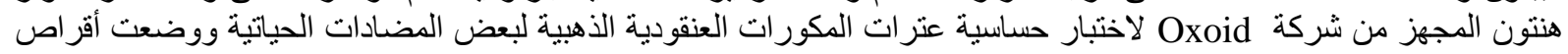

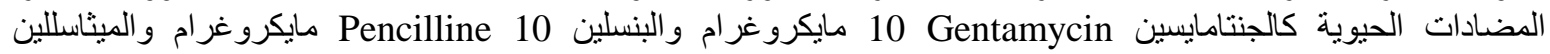

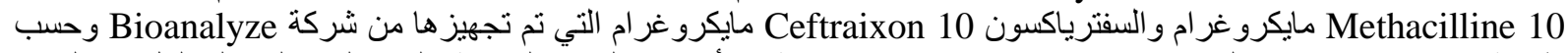

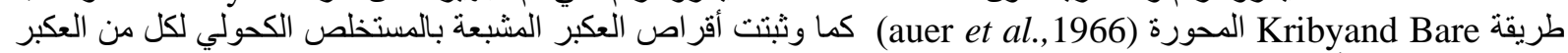

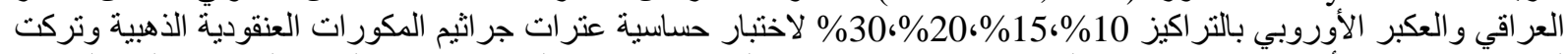

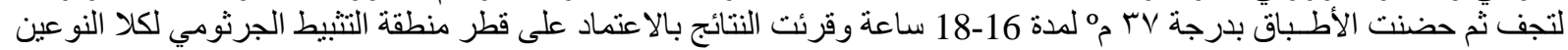

من العكبر وللمضادات الحياتية (Carter and Wise, 2004; Hendrix, 2002).

\section{RESULTS}

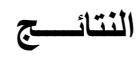

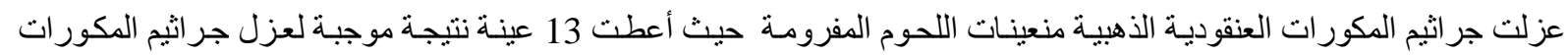

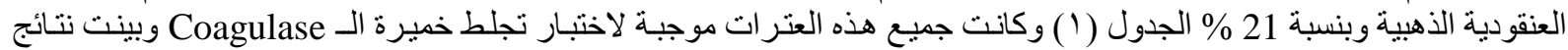

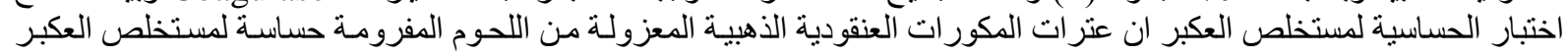




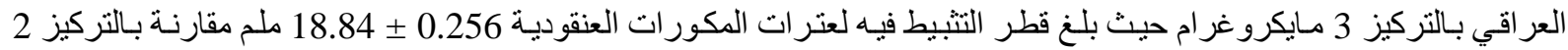

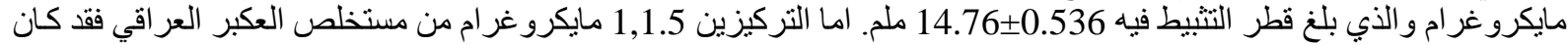

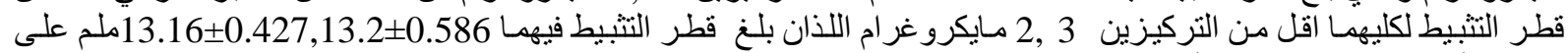

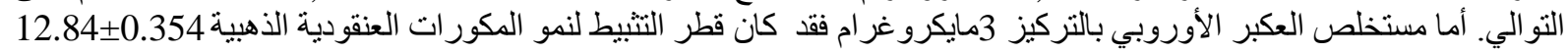

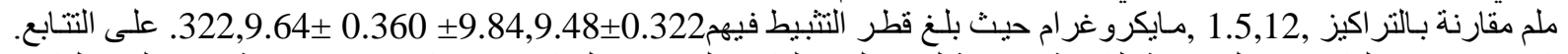

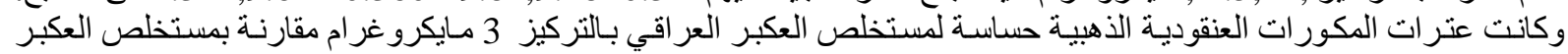

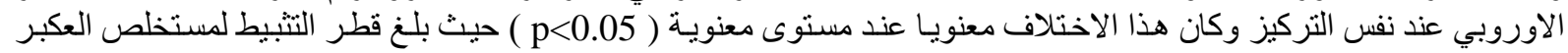

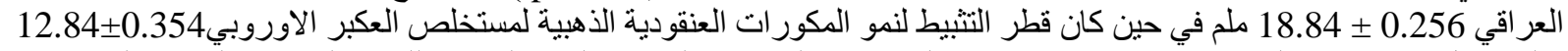

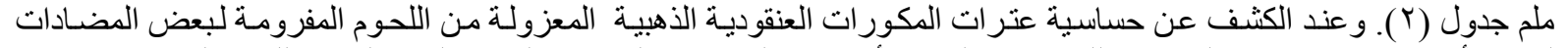

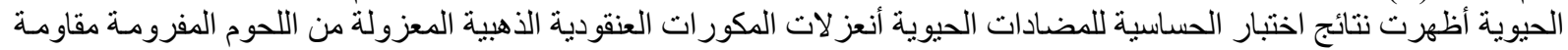

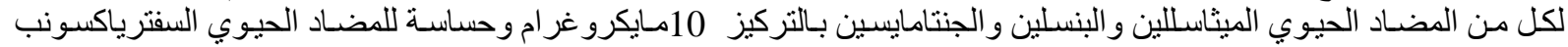

التركيز 10 مايكروغرام شكل (1)

الجدول ا : النسبة المئوية لعزل المكورات العنقودية الذهبية من اللحوم المفرومة.

\begin{tabular}{|c|c|c|c|}
\hline النسبة المئوية & & 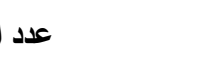 & عدد العينات المفحوصة \\
\hline $21 \%$ & 13 & العينات الموجبة & \multirow{2}{*}{60} \\
\hline $79 \%$ & 47 & العينات السالبة & \\
\hline $100 \%$ & \multicolumn{2}{|c|}{60} & المجموع \\
\hline
\end{tabular}

الجدول r : معدل قطر تثبيط نمو المكورات العنقودية الذهبية بمستخلص العكبر العر اقي والأوروبي.

\begin{tabular}{|c|c|c|c|c|}
\hline \multicolumn{4}{|c|}{ تراكيز العكبر } & \multirow[t]{2}{*}{ نوع العكبر } \\
\hline$\% 30$ & $\% 20$ & $\% 15$ & $\% 10$ & \\
\hline $12.84 \pm 0.354$ & $9.48 \pm 0.322$ & $9.84 \pm 0.293$ & $9.64 \pm 0.36$ & \\
\hline c & $\mathrm{d}$ & $d$ & $\mathrm{~d}$ & العكبر الاوروبي \\
\hline $18.84 \pm 0.256$ & $14.76 \pm 0.536$ & $13.2 \pm 0.586$ & $13.16 \pm 0.427$ & \\
\hline $\mathrm{a}$ & $\mathrm{b}$ & $\mathrm{c}$ & $\mathrm{c}$ & العكبر العراقي \\
\hline
\end{tabular}

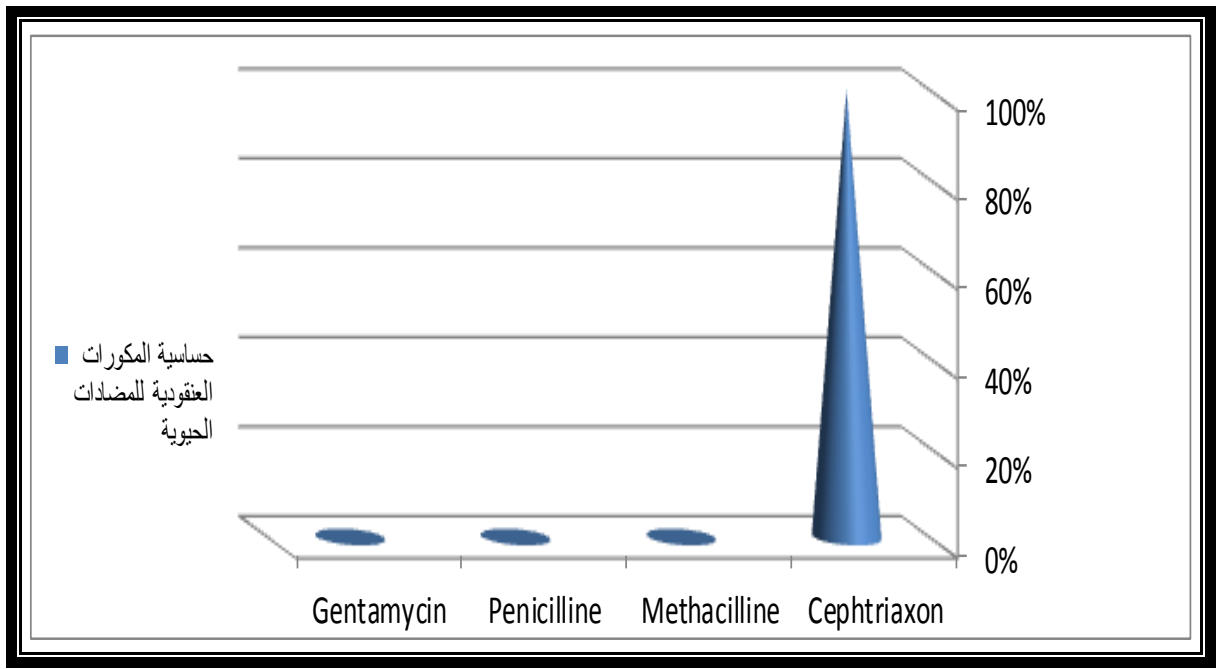

الثكل ( (1): حساسية المكور ات العنقودية الذهبية المعزولة من اللحوم المفرومة لبعض المضادات الحباتية 


\section{DISCUSSION}

\section{المناقشـــة}

بلغت نسبة عزل المكور ات العنقوديـة الذهبيـة من اللحوم المحلية في الدر اسـة الحالية 21\% وكانت هذه النسبة اقل من نسبة عزل

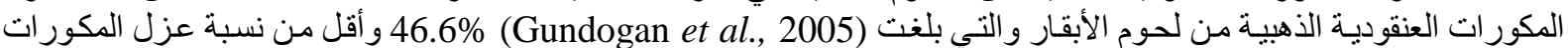

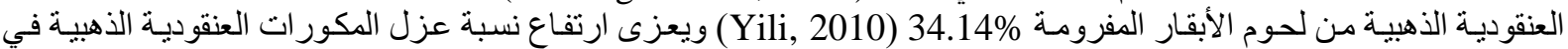

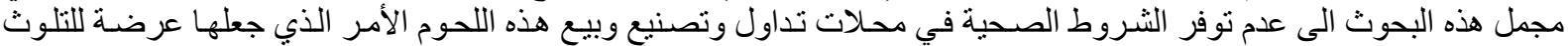

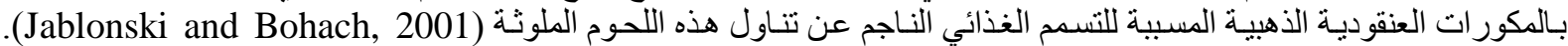

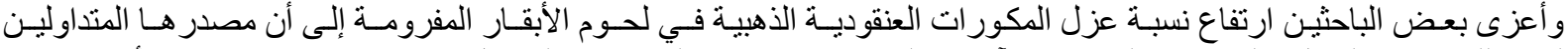

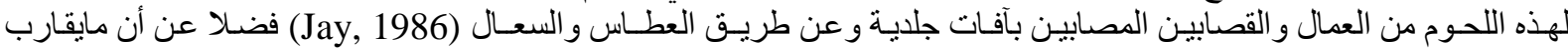

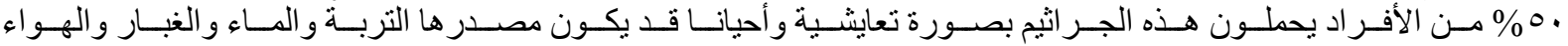

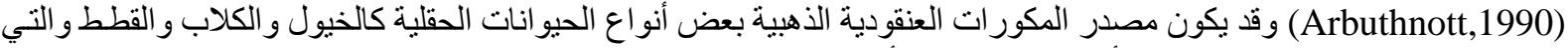

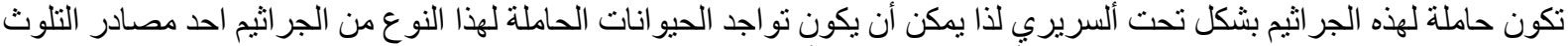

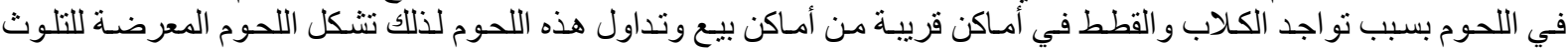

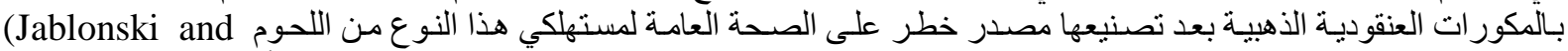
Bohach, 2001)

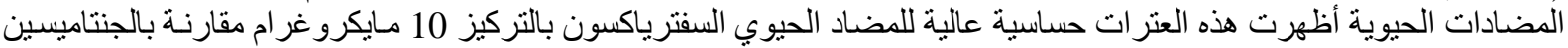

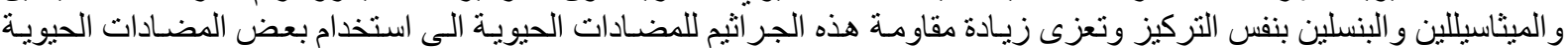

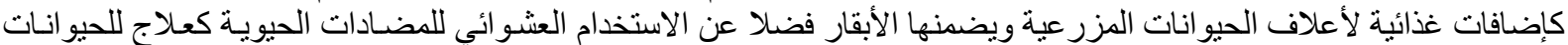

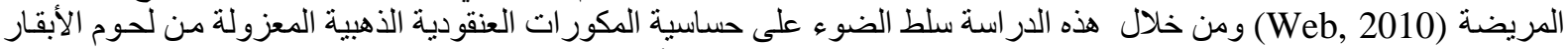

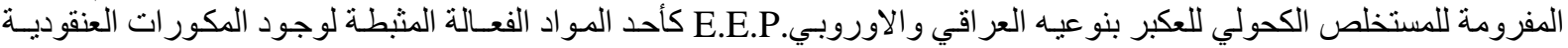

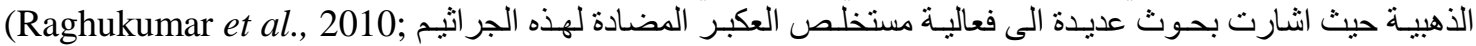
فضـلا عن مـا توصل Kilic et al, 2005; Fernandes et al., 2003; Fernandes et al., 2001; Sforcin et al., 2000) إليها لباحث (yaghoubi et al., 2007) من ان عتر ات الجر اثيم موجبة الكر ام اكثر حساسية للعكبر من عنر ات الجر اثيم سـالبة

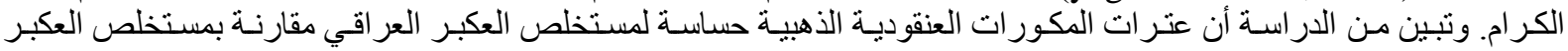

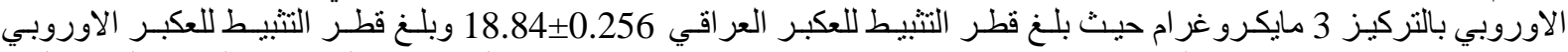

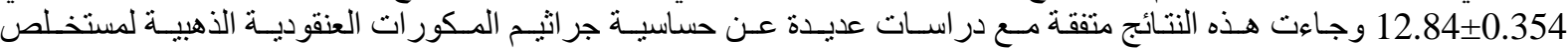

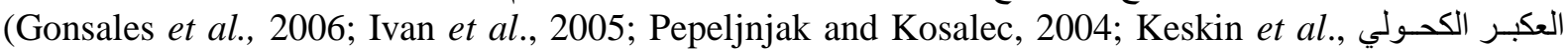
2001; Kujumgiev et al., 1999; Park et al., 1998; Krol et al., 1993; Detoma and Ozin, 1991)

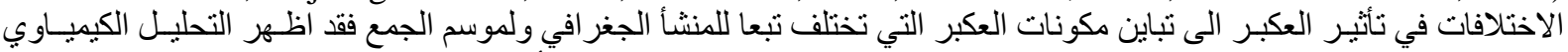

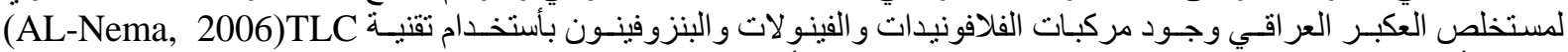

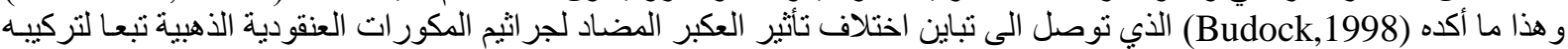

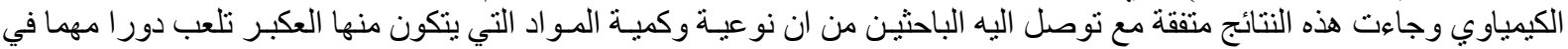

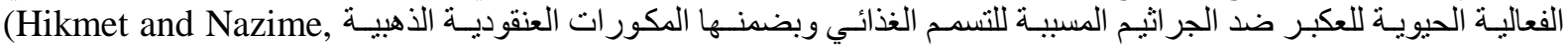
2006; Santos et al., 2002; Hegazi and Abd El Hady, 2001; Hegazi et al., 2000a; Hegazi et al., 2000b; Kujumgiev et al., 1999) ; وفي در اسـة أجر اهـا الباحث (Popova et al., 2007) على مستخلص العكبر الكحولي لمنـاطق مختلفة من اوربا والثرق الاوسط تبين ان مستخلص العكبر يحتوي على الفلافونيدات و التي تضم الفي الفلافونون flavonon و والفلافون

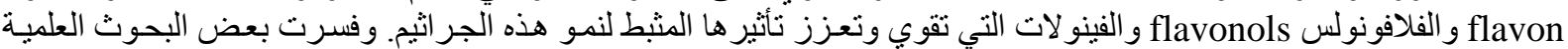

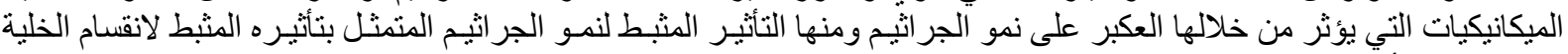

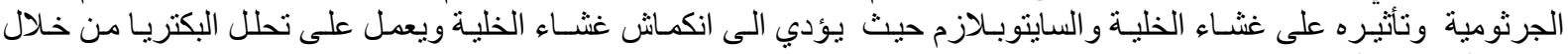

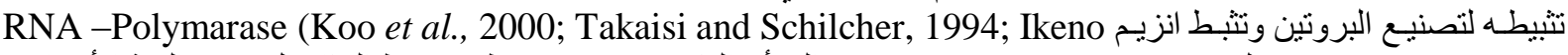

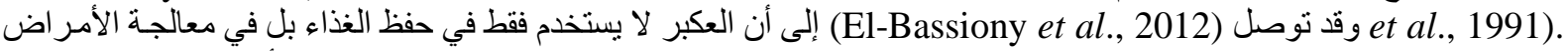

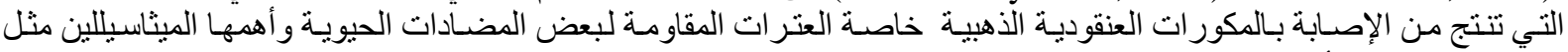

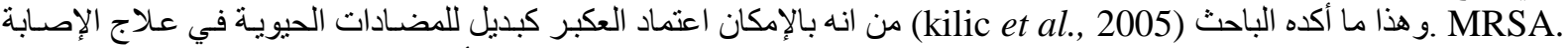

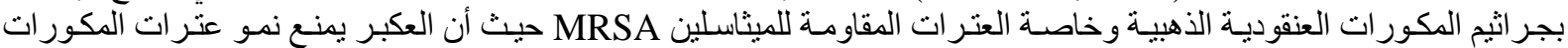

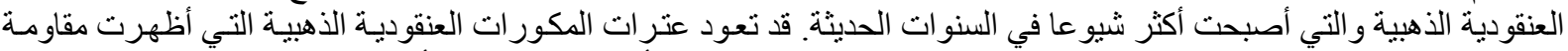

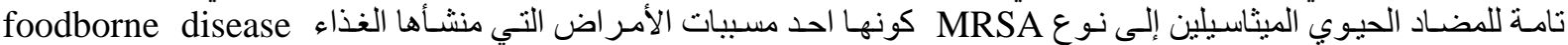

.(Raghukumar et al., 2010 ) 


\section{REFERENCES \\ المراجع}

Akao, Y.; Maruyama, H.; Matsumoto, K.; Ohguchi, K.; Nishizawa, K. Sakamato, T.; Araki, Y.; Mishima, S. and Nozawa, Y. (2003): Cell growth inhibitory effect of cinnamic acid derivatives from propolis on human cell line s. Pharmaceut. Bull. 26(7):1075-1095.

AL-Nema, M.M. (2006): An Analytical and histological study of a new roof canal filling material composed of Iraqi propolis, beeswax and vanillin, P.H.D. thesis The College of Dentistry, University of Baghdad.

Arbuthnott, J.P. (1990): Staphylococcal toxins in human disease. Journal of Applied Bacteriology Supplement,101S-107S .

Bankova, V.; Popova, M.; Bogdanov, S. and Sabatini, A. (2002): Chemical composition of European propolis: expectedand unexpected results. Z. Naturforsch; 57: 530-533.

Bauer, A.W.; Kirby, W.N.; Sheris, J.C. and Tuck, M. (1966): Antibioticsusceptibility by standard single disc method. Am. J. Clin. Pathol. 36: 493-496.

Burdock, G.A. (1998): Review of the biological properties and toxicity of bee propolis (propolis), Food Chem. Toxicol. 36: 347-363.

Cardile, V.; Panico, A.; Gentile, B.; Borrelli, F. and Russa, A. (2003): Effect of propolis on human cartilage and chondrocytes. Life Sci , 1027-1035.

Carter, GR. and Wise, DG. (2004): Essentials of Veterinary Bacteriology and Mycology.6 thed Iowa State Press. USA. pp: 82- 83.

Castaldo, S. and Capasso, F. (2002): Propolis, an old remedy used in modern medicine. Fitoterapia; 73 Suppl 1: 51-56.

Celik, S.; Gorur, S.; Aslantas, O.; Erdogan, S.; Ocak, S. and Hakverdi, S. (2007): Caffeic acid phenethyl ester suppresses oxidative stress in Escherichia coliinduced pyelonephritis in rats. Mol. Cell. Biochem. 297(1-2): 131-138.

Cilli, N.; Barbara, M.; Luana, K. Di-agam, S.M.; Cosmo, R. and Domenico, R. (2004): Development and validation of a liquid chromatographic-tandem mass spectrometric method for the determination of caffeic acid phenethyl ester in rat plasma and urine. Journal of Chromatography, 810: 129-136.

Detoma, P. and Ozin, O.I. (1991): Propolis activity on microorganism from hospital source. Ann. Microbiol., 41: 231-236.

El-Bassiony, T.A.; Saad, N.M. and El-Zamkan, M.A. (2012): Study on the antimicrobial activity of Ethanol Extract of Propolis against Methicillin - Resistant Staphylococcus aureus in lab prepared Ice - cream. Vet. World, 5 (3): 155-159.

Fernandes, J.A.; Balestrin, E.C.C. and Cunha, M.L.R.S. (2003): Anti-Staphylococcus aureus activity of bee propolis extracts prepared with different ethanol concentrations. Rev. Cienc. Farm. 24: $147-152$.

Fernandes, J.A.; Leomil, L.; Fernandes, A.A.H. and Sforcin, J.M. (2001): The antibacterial activity of propolis produced by Apismellifera L. and Brazilian stingless bees. J. Venom. Anim. Toxins 7: 173-182.

Gonsales, G.Z.1.; Orsi, R.O.1.; Fernandes Junior, A.II.; Rodrigues, P.I and Funari, S.R.C.I. (2006): Antibacterial activity of propolis collected in different regions of Brazil. J. Venom. Anim. Toxins incl. Trop. Dis vol.12 (20): 276-284.

Gundogan, N.; Citak, S.; Yucel, N. and Devren, N. (2005): A noteonthe incidence and antibiotic resistance of Staphylococcus aureus isolated from meat and chicken samples. Meat sci. 69:807810.

Havsteen, B. (2002): The biochemistry and medicinal significance of flavonoids. Pharmacol Therapeu. 96: 67-202.

Hegazi, A.G.; Abd El Hady, F.K. and Abd Allah, F.A.M. (2000a): Chemical composition and antimicrobial activity of European propolis. Z. Naturforsch. 55. 71-75.

Hegazi, A. and Abd El Hady, F. (2001): Egyptian propolis: 1. Anti antimicrobial activity and chemical composition of upper Egypt propolis. Z. Naturforsch; 56(1-2): 82-8. 
Hegazi, A.G.; Farghali, A.A. and Abd El Hady, F.K. (2000b): Antiviral activity and chemical composition of European and Egyptian propolis In: International Conference of Propolis Argentina, September: 99.

Hendrix, CM. (2002): Laboratory Procedures for Veterinary Technicians. $4^{\text {th }}$ ed Mosby, USA.: 217218.

Hikmet, K. and Nazime, M. (2006): Antimicrobial activity and chemical compositions of Turkish propolis from different region. African Journal of Biotechnology. 5(11):1151-1153.

Ikeno, K.; Ikeno, T. and Miyazawa, C. (1991): Effects of propolis on dental caries in rats. Caries Res 25: 347-351.

Ishida, V.F.C.G.; Negri, A.; Salatino, and Bandeira, M.F.C.L. (2011): "Anewtype of Brazilian propolis: prenylatedbenzophenonesinpropolis from Amazonanects against cariogenicbacteria," Food Chemistry. 125 (3): 966-972.

Ivan, K.M.; Pepeljnjak, S.; Bakmaz, M. and Vladmir-Knezevic, S. (2005): Flavonoid analysis and antimicrobial activity of commercially available propolis products. Acta Pharm. 55: 423-30.

Jablonski, L.M. and Bohach, G. (2001): Staphylococcus aureus. In M.P. Doyle, L.R. Beuchat and T.J. Montvill, Food microbiology: Fundamentals and frontiers. Washington. DC: ASM Press.

Jay, J. (1986): Staphylococcal gastroenteritis. In modern food microbiology (3rded.) New York: Van Nostrand Reinhold. 437-458.

Kartal, M.; Yildiz, S.; Kaya, S.; Kurucu, S. and Topси, G. (2003): Antimicrobial activity of propolis samples from two different regions of Anatolia. J. Ethnopharmacol. 86: 69-73.

Keskin, N.; Hazir, S.; Baser, K.H. and Kurkcuoglu, M. (2001): Antibacterial activity and chemical composition of Turkey propolis. Z Naturforsch. 56(11-12): 1112-1115.

Kilic, A.; Baysallar, M.; Besirbellioglu, B.; Salih, B.; Sorkun, K. and Tanyuksel, M. (2005): In vitro antimicrobial activity of propolis against -methicillin-resistant S.aureus and vancomycinresistant Enterococcus faecium. Annals of Microbiol. 55:113-117.

Kloos, W.E. and Lambe, D.W. (1991): Staphylococcus. in: Manual of Clinical Microbiology. A.balows, W.J.; Hausler, K.; Herrman, H.; Isenberg and H.J. Shadomy. American Society for Microbiology. Washington, DC. 222-237.

Koo, H.; Rosalen, P.L.; Cury, J.A.; Ambrosano, G.M.B.; Murata, R.M. and Yatsuda, R.; (2000): Effect of a new variety Apismellifera propolis on mutans Streptococci. Curr Microbiology; 41:192-4.

Kosalec, I.; Bakmas, M. and Pepeljnjak, S. (2003): Analysis of propolis from continental and Adriatic regions of Croatia. Aeta pharm. 53:275-285.

Kosalec, I.; Bakmaz, M.; Vladimir-Knezevic, S. and Pepeljnjak, S. (2004): Quantitative analysis of the flavonoids in raw propolis from northern Croatia, Acta Pharm. 54: 65-72.

Krell, R. (1996): Value added products from beekeeping FAO Agricultural Services Bulletin No. 124. Chapter V. http://www.fao.org/docrep/w0076e/w 0076e00.htm.

Krol, W.; Scheller, S.; Shani, J.; Pietsz, G. and Czuba, Z. (1993): Synergistic effect of ethanolic extract of propolis and antibiotics on the growth of Staphvlococcus aureus. Arzneimittel-forsch 43: 607-609.

Kujumgiev, A.; Tsvetkova, I.; Serkedjieva, Y.; Bankova, V.; Christov, R. and Propov, S. (1999): Antibacterial, antifungaland antiviral activity of propolis of different geographic origin. Ethnopharmacol. 63(3): 235-40.

Lu, L.; Chen, Y. and Chou, Ch. (2005): Antibacterial activity of propolis against Staphylococcus aureus. Inter. J. Food Microbiology.102: 213-220 .

Martin, S.E. and Myers, E.R. (1994): Staphylococcus aureus. in: Food borne Disease Hand book. Diseases Caused by bacteria. Vol.1.Y.H. Hui, J.R. Gorham, K.D. Murrell and D.O. Cliver, Marcel Dekker Inc., New York. NY. 345-394.

National Committee for Clinical Laboratory Standards, NCCLS. (2004): Performance standards for antimicrobial susceptibility testing; $14^{\text {th }}$ informational supplement Wayne, PA, USA. 24(1): M100-S14.

Park, Y.K.; Koo, M.H.; Abreu, J.A.S.; Ikegaki, M.; Cury, J.A. and Rosalen, P.L. (1998): Antimicrobial activity of propolis on oral microorganisms. Curr.Microbiol. 36:24-28. 
Pepeljnjak, S. and Kosalec, I. (2004): Galangin expresses bactericidal activity against multipleresistant bacteria: MRSA, Enterococcus spp. and pseudomonas aeruginosa. FEMS. Microbial. Lett. 240:111-116.

Popova, M.P.; Bankova, V.S.; Bogdano, S.; Tsvetkova, I.; Naydenski, C.; Marcazzan, G.L. and Sabatin, A.G. (2007): Chemical characteristics of popular type propolis of different geographic origin. Apidologie 38, 306-311.

Prytzyk, E.; Dantas, A.P.; Salomao, K.; Pereira, A.S.; Bankova, V.S.; DeCastro, S.L. and AquinoNeto, F.R. (2003): Flavonoids and trypanocidal activity of Bulgarian propolis. J. Ethnopharmacol. 88:189-193.

Raghukumar, R.; Vali, L.; Watson, D.; Fearnley, J. and Seidel, V. (2010): Antimethicillin-resistant S.aureus (MRSA) Activity of pacific propolis and Isolatedprenylflavanones. Phytother. Res. (www.interscience. Wiley.com) DOI:10.1002/prt.3096.

Santos, F.A.; Bastos, E.M.A.; Uzeda, B.; Carvalho, M.A.R.; Farias, E.S.A. and Braga, F.C. (2002): Antimicrobial activity of Brazilian propolis and fractions against oral Anaerobic bacteria. Ethnopharmacol. 80:1-7.

Schlegelova, J.; Napravnikova, E.; Dendis, M.; Horvath, R.; Benedik, J. and Babak, V. (2004): Beef carcass contamination in slaughterhouse and prevalence of resistance to antimicrobial drugs in isolates of selected microbial species. Meat Science. 66: 557-565.

Sforcin, J.M.; Femandes, J.A.; Lopes, C.A.M.; Bankova, V. and Funari, S.R.C. (2000): Seasonal effect on Brazilian propolis antibacterial activity. J. Ethnopharmacol. 73: 243-249.

Takaisi-Kikuni, N.B. and Schilcher, H. (1994): Electron microscopy and microcalorimetric investigations of the possible mechanism of the antibacterial action of a defined propolis provenance. Planta. Medica 60:222-227.

Wang, B.J.; Lien, Y.H. and Yu, Z.R. (2004): Supercritical fluid extractive fractionation study of the antioxidant activities of propolis. Food Chem. 86: 237-243.

Webmd. (2010): http:// www. Webmd.com/skin-problems -and -treatments /understanding -mrsamithacillin-resistant-staphylococcus aureus.

Yaghobi, S.M.J.; Ghorbani, G.R.; Soleimanian, Z.S. and Satari, R. (2007): Antimicrobial activity of Iranian propolis and its chemical composition. DARU Vol.15, (1).

Yili (2010): Isolation and characterization of antimicrobial resistant Staphylococcus aureus in retail ground meats. M.S. Thesis, University of Maryland. 